\title{
A Case Report of Carcinoma ex Pleomorphic Adenoma
}

\section{HARPREET GREWAL ${ }^{*_{1}}$, KESARI SINGH², VASUDHA BHAGAT ${ }^{3}$}

Carcinoma ex-pleomorphic non-malignant tumour (Ca ex PA, CXPA) is a rare, aggressive, poorly understood malignancy of the exocrine gland. The clinical findings typical of this neoplasm embrace history of a slow growing, ulcerated, painless mass that enlarges speedily. The current definition of Ca ex PA became widely accepted in the second half of the twentieth century. It is uncommon, having a prevalence rate of 5.6 cases per 100,000 malignant neoplasms and a yearly incidence rate of 0.17 tumours per 1 million persons in the world. The cancer is found predominantly in the sixth to eighth decades of life and is slight female predilection.

KEYWORDS: Ex-pleomorphic, Tumour, Malignant, Carcinoma

\section{INTRODUCTION}

Carcinoma ex pleomorphic adenoma (Ca ex PA, CXPA) is type of rare, aggressive, poorly understood malignancy usually occurring in the salivary glands and accounts for most cases of malignant mixed tumors reported in the literature. ${ }^{-3}$ It is also known as carcinoma ex mixed tumor, carcinoma ex adenoma, and carcinoma ex benign pleomorphic adenoma. ${ }^{4}$ It was first described by Beahrs et al. in 1957 and accounts for 3. $6 \%$ of all salivary gland neoplasms and for $11.7 \%$ of salivary malignancies. ${ }^{5}$

Various authors state that Carcinoma ex pleomorphic adenoma usually occurs in the $6^{\text {th }}-8^{\text {th }}$ decades of life. ${ }^{5,6}$ As per the histological classification report of the World Health Organization (2005), the so called "malignant mixed tumors," are divided into 3 different clinical and histologic entities: 1) carcinoma ex pleomorphic adenoma (carcinoma in pre-existing pleomorphic adenoma), 2) carcinosarcoma (true malignant mixed tumor), and 3) metastasizing pleomorphic adenoma. Literature search reveals that most malignant mixed tumors are carcinoma ex pleomorphic adenoma, whereas the latter 2 types are extremely unusual and rarely reported. ${ }^{7}$

The gold standard for making an accurate diagnosis is pathological assessment and its treatment often involves an ablative surgical procedure, which may be followed by radiotherapy. It has been stated that patients with CXPA have a poor prognosis. This case report presents a case of Carcinoma ex pleomorphic adenoma affecting a 48 year old male patient.

\section{CASE REPORT}

A 48 year old male patient came to the department of Oral Medicine and Radiology with a chief complaint of a growth on the left side of the face since two years. The growth was initially small and gradually increased to the present size. There was history of associated pain since 1 month. Medical and past dental histories were non-relevant. General physical examination was non-contributory. Extra-oral examination revealed a growth of size $5 \times 6 \mathrm{cms}$ on the left side of the face extending anteroposteriorly $2 \mathrm{cms}$ from corner of mouth to $5 \mathrm{cms}$ posteriorly to the ear lobe. The post auricular area had a $7 \times 8 \mathrm{~mm}$ growth [Figure 1(a) and (b)]. Skin over the growth was normal. There was no surface rise in temperature. It was slightly tender on palpation, soft-firm in consistency. It was nonfluctuant, slightly compressible but non reducible.

Diascopy test was negative. On intra-oral examination, no abnormality was detected. On the basis of history and clinical examination of the growth, a provisional diagnosis of a malignant tumor of the salivary gland was given. A differential diagnosis of other malignant tumors was considered. The patient was sent for further investigations which included MRI (Figure 2) which confirmed the diagnosis of Carcinoma ex Pleomorphic Adenoma

\section{DISCUSSION}

Pleomorphic adenoma is the most common benign salivary gland neoplasm. ${ }^{8}$ The terms pleomorphic adenoma and mixed tumor both represent attempts to describe this tumor's interesting histopathologic 
features. Malignant mixed tumors represent malignant counterparts to the benign mixed tumor or pleomorphic adenoma. These are a group of rare neoplasms which constitute $2 \%$ to $6 \%$ of all salivary gland tumors. ${ }^{8,9}$

The most common of these is the carcinoma ex pleomorphic adenoma, which is characterized by malignant transformation of the epithelial component of a previously benign pleomorphic adenoma. The carcinosarcoma is a rare "mixed" tumor in which both carcinomatous and sarcomatous elements are present. The metastasizing mixed tumor has histopathologic features that are identical to the common pleomorphic adenoma. The lesion metastasizes despite its benign appearance. The metastatic tumor also has a benign microscopic appearance, usually similar to that of the primary lesion. ${ }^{8-10}$

Carcinoma ex pleomorphic adenoma can be regarded as a malignant change in the previous benign tumor. The age of the patients is older than those affected by pleomorphic adenoma. Patients report of a growth present since many years and a recent history of pain can be reported."

It is most common in the parotid salivary glands. This is similar to the location of the tumor in the present case. Intra-orally, two-thirds of the cases have been documented on the palate. Ulceration may also be present.

Histopathologically, areas of typical benign pleomorphic adenoma usually can be found and may constitute most or only a small portion of the lesion. Within the tumor are areas of malignant degeneration of the epithelial component characterized by cellular pleomorphism and abnormal mitotic activity. ${ }^{12}$

The differential diagnosis includes other malignant tumors such as mucoepidermoid carcinoma, adenoid cystic carcinoma, acinic cell carcinoma. ${ }^{13}$

Treatment plan includes complete parotidectomy with preservation of the facial nerve. Radiation therapy also has been proven useful. Well differentiated tumors have a favorable prognosis whereas poorly differentiated tumors have poor prognosis.

\section{REFERENCES}

1. Bhat VS, Biniyam K, Aziz AA, Yeshwanth SK. Carcinoma ex-pleomorphic adenoma of submandibular salivary gland: A case report and review of literature. J NTR Univ Health Sci 2017;6:185-8.

2. Antony J, Gopalan V, Smith RA, Lam AKY. Carcinoma ex Pleomorphic Adenoma: A Comprehensive Review of Clinical, Pathological and Molecular Data. Head Neck Pathol. 2012;6(1):19.

3. Keerthi R, Raut RP, Vaibhav N, Ghosh A. Carcinoma ex pleomorphic adenoma: Diagnostic dilemma and treatment protocol. Indian J Dent. 2014 Jul-Sep; 5(3): 157-6o.

4. Nouraei SA, Hope KL, Kelly CG, McLean NR, Soames JV. Carcinoma ex benign pleomorphic adenoma of the parotid gland. Plast Reconstr Surg. 2005;116:1206-13.

5. Chen HH, Lee LY, Chin SC, Chen IH, Liao CT, et al. Carcinoma ex pleomorphic adenoma of soft palate with cavernous sinus invasion. World J Surg Oncol 2010;8:24.

6. Tamgadge S, Tamgadge A, Pereira T, Naik S. Carcinoma Ex Pleomorphic Adenoma: Rare Malignant Salivary Gland Neoplasm. Oral Hyg Health 2014;2(3):132.

7. Kato H, Kanematsu M, Mizuta K, Ito Y, Hirose Y. Carcinoma Ex Pleomorphic Adenoma of the Parotid Gland: Radiologic-Pathologic Correlation with MR Imaging Including Diffusion-Weighted Imaging. American Journal of Neuroradiology May 2008;29(5):865-7.

8. Neville B, Douglas DD, Carl C, Chi A. Salivary gland pathology $4^{\text {th }}$ ed.

9. Shafer's textbook of Oral Pathology 8th ed.

10. Maruthamuthu T, Saniasiaya J, Mohamad I, Nadarajah S, Lazim NM, Wan Abdul Rahman WF. Carcinoma Ex Pleomorphic Adenoma Presented as a Gigantic Tumor: Treatment and Diagnostic Challenges. Oman Med J 2018;33(4):342-5.

11. Jain S, Hasan S, Vyas N, Shah N, Dalal S. Pleomorphic Adenoma of the Parotid Gland: Report of a Case With Review of Literature. Ethiop J Health Sci. 2015; 25(2):189-94.

12. Rahnama M, Koszel U, Czupkałło L, Łobacz M. Pleomorphic adenoma of the palate: a case report and review of the literature. Contemp Oncol (Pozn). 2013;17(1):103-6.

13. de Silva MN, Kosgoda KMS, Tilakaratne WM, Murugadas P. A case of giant pleomorphic adenoma of the parotid gland. Oral Oncol 2004;40(3):43-5. 
Source of support: Nil, Conflict of interest: None declared

\section{Cite this article as:}

Grewal H, Singh K, Bhagat V. A Case Report of C Adenoma . Int Healthc Res J. 2018;2(8):192-194.
193 leomorphic arj.v2i8.169

\section{AUTHOR AFFILIATIONS:}

1. Professor \& Head of Department, Department of Dentistry, GTBH \& UCMS, Delhi

2. Senior Resident, Department of Dentistry, GTB Hospital, Delhi

3. PG Student, Department of Oral Medicine and Radiology, DJ College of Dental Sciences and Research, Modinagar

\section{${ }^{*}$ Corresponding Author:}

Dr. Harpreet Grewal

Professor \& Head of Department

Department of Dentistry

GTBH \& UCMS, Delhi
For article enquiry/author contact details, e-mail at: editor.ihri@gmail.com, editor@ihrjournal.com

\section{LEGENDS}
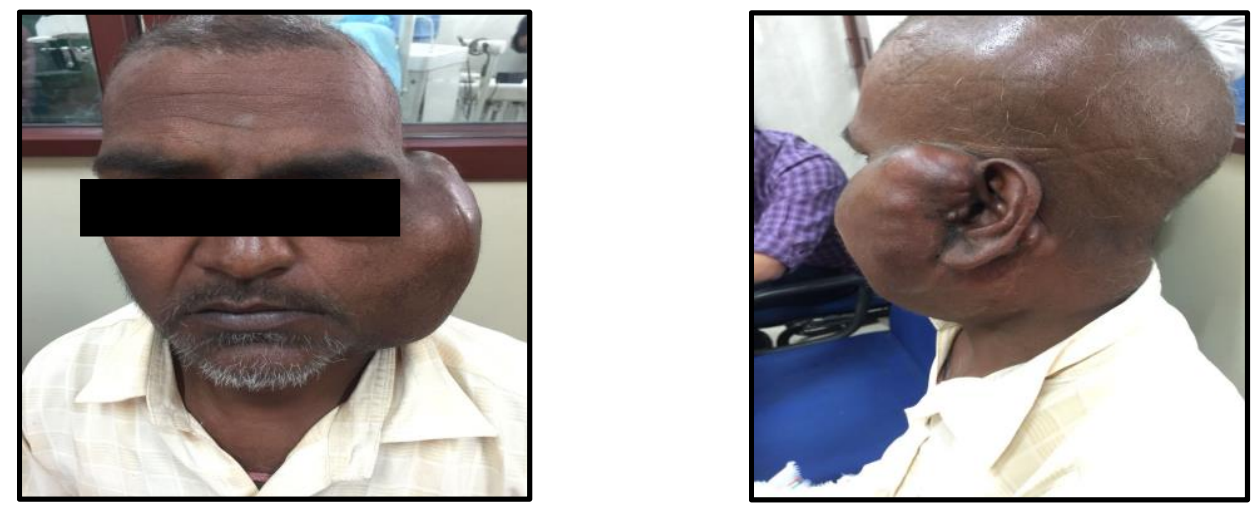

Figure $1(\mathbf{a})$ and (b). Growth on the left side of the face of the patient since two years

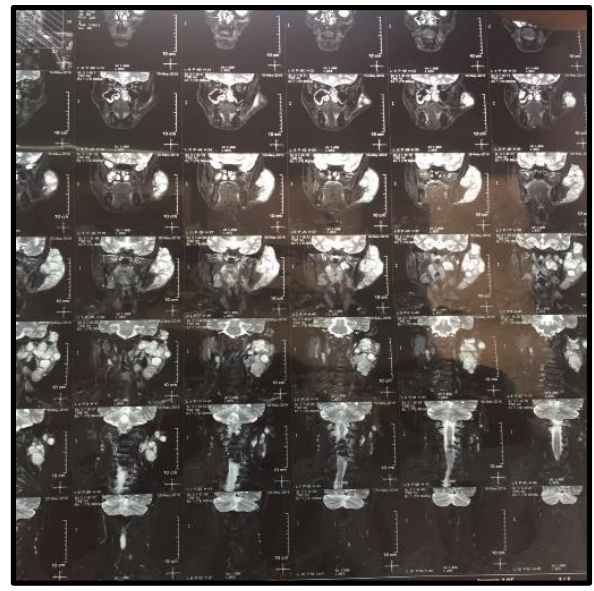

Figure 2. MRI of the lesion confirming the diagnosis 